\title{
Investigation of the stallion sperm proteome by mass spectrometry
}

\author{
Aleona Swegen, Benjamin J Curry, Zamira Gibb, Sarah R Lambourne, Nathan D Smith ${ }^{1}$ \\ and R John Aitken \\ Priority Research Centre for Reproductive Science, School of Environmental and Life Sciences, University of \\ Newcastle, Callaghan, New South Wales 2308, Australia and ${ }^{1}$ Analytical and Biomedical Research Facility, \\ Research Division, University of Newcastle, Callaghan, New South Wales, Australia
}

Correspondence should be addressed to A Swegen; Email: aleona.swegen@uon.edu.au

\begin{abstract}
Stallion spermatozoa continue to present scientific and clinical challenges with regard to the biological mechanisms responsible for their survival and function. In particular, deeper understanding of sperm energy metabolism, defence against oxidative damage and cell-cell interactions should improve fertility assessment and the application of advanced reproductive technologies in the equine species. In this study, we used highly sensitive LC-MS/MS technology and sequence database analysis to identify and characterise the proteome of Percoll-isolated ejaculated equine spermatozoa, with the aim of furthering our understanding of this cell's complex biological machinery. We were able to identify 9883 peptides comprising 1030 proteins, which were subsequently attributed to 975 gene products. Gene ontology analysis for molecular and cellular processes revealed new information about the metabolism, antioxidant defences and receptors of stallion spermatozoa. Mitochondrial proteins and those involved in catabolic processes constituted dominant categories. Several enzymes specific to $\beta$-oxidation of fatty acids were identified, and further experiments were carried out to ascertain their functional significance. Inhibition of carnitine palmitoyl transferase 1, a rate-limiting enzyme of $\beta$-oxidation, reduced motility parameters, indicating that $\beta$-oxidation contributes to maintenance of motility in stallion spermatozoa.

Reproduction (2015) 149 235-244
\end{abstract}

\section{Introduction}

The rendezvous of highly sensitive proteomic technologies with the study of sperm cell biology provides unique opportunities for insights into reproductive physiology. Spermatozoa are highly specialised cells evolved for the single purpose of fertilisation and left with only the most essential of structures, having eliminated most of their cytoplasm and lost the ability to transcribe genes into new proteins. The functional transformation of these cells after they are released from the germinal epithelium of the testes depends entirely upon changes in their protein composition, including the removal and addition of entire proteins and a complex array of post-translational modifications responsible for driving the structural and functional changes to these cells commensurate with epididymal maturation and capacitation (Gadella 2008, Baker et al. 2012, Cornwall 2014, Dacheux \& Dacheux 2014). Thus, these unique cells are excellent candidates for proteomic study, and the protein profile of ejaculated spermatozoa can provide us with a great deal of information concerning their fundamental cell biology (Amaral et al. 2014). Our knowledge of stallion spermatozoa in particular would benefit from such an analysis, given that this species has shown itself to be distinct in many aspects of its reproductive physiology and posed many obstacles to those aiming to develop sperm cryopreservation (Loomis \& Graham 2008) and sex pre-selection (Morris 2005), IVF (Galli et al. 2014) and fertility diagnostics (Ball 2008, Varner 2008) in the stallion.

Recent improvements in the power and resolution of mass spectrometers have resulted in a sudden explosion of information concerning the proteomic structure of mammalian spermatozoa. Detailed proteomic inventories are now available for human (Baker et al. 2007), mouse (Baker et al. 2008a), rat (Baker et al. 2008b) and bull spermatozoa (Byrne et al. 2012). In the case of the horse, major stallion seminal plasma proteins have been identified and found to have roles in fertilisation (reviewed in Leeb et al. (2005)), and several proteins in spermatozoa and seminal plasma have been correlated with stallion fertility (Gamboa \& Ramalho-Santos 2005, Novak et al. 2010). Stallion epididymal fluid (Fouchecourt et al. 2000) and epididymal spermatozoa (Dias et al. 2014) have been subjected to proteomic investigation, laying down a foundation of several hundred proteins potentially involved in equine sperm 
epididymal maturation and already indicating speciesspecific characteristics of this process in the stallion. However, whole ejaculated equine spermatozoa have not yet been subjected to comprehensive proteomic analysis. This study employed mass spectrometry and bioinformatics to produce a list of proteins found in mature stallion spermatozoa and subsequently explored the role of $\beta$-oxidation-associated enzymes in sperm metabolism. Specifically, we investigated the presence of carnitine palmitoyl transferase 1 (CPT1), the ratelimiting enzyme of mitochondrial $\beta$-oxidation of fatty acids, and demonstrated that inhibition of this enzyme in vitro restricts the ability of spermatozoa to maintain normal motility.

\section{Materials and methods}

\section{Materials}

All chemicals were purchased from Sigma-Aldrich unless otherwise stated. A modified Biggers, Whitten and Whittingham (BWW) medium (Whitten \& Biggers 1968) containing $95 \mathrm{mM}$ $\mathrm{NaCl}, 4.7 \mathrm{mM} \mathrm{KCl}, 1.7 \mathrm{mM} \mathrm{CaCl}{ }_{2} \cdot 2 \mathrm{H}_{2} \mathrm{O}, 1.2 \mathrm{mM} \mathrm{KH}_{2} \mathrm{PO}_{4}$, $1.2 \mathrm{mM} \mathrm{MgSO}_{4} \cdot 7 \mathrm{H}_{2} \mathrm{O}, 25 \mathrm{mM} \mathrm{NaHCO}, 5.6 \mathrm{mM}$ D-glucose, $275 \mu \mathrm{M}$ sodium pyruvate, $3.7 \mu \mathrm{l} / \mathrm{ml} 60 \%$ sodium lactate syrup, $50 \mathrm{U} / \mathrm{ml}$ penicillin, $50 \mu \mathrm{g} / \mathrm{ml}$ streptomycin, $20 \mathrm{mM}$ HEPES and $0.1 \%(\mathrm{w} / \mathrm{v})$ polyvinyl alcohol, with an osmolarity of $\sim 310 \mathrm{mOsm} / \mathrm{kg}$, was utilised throughout this study.

\section{Preparation of spermatozoa}

Institutional and New South Wales State Government ethical approval was secured for the use of animal material in this study.

Equine spermatozoa were collected from normozoospermic pony stallions $(n=3)$ using a pony-sized Missouri artificial vagina (Minitube Australia, Ballarat, VIC, Australia). Stallions were of mixed pony breeds, aged between 7 and 10 years and proven to be fertile. They were kept on temperate climate pasture and grass hay, on institutionally approved premises. Samples to be used for proteomic analysis were not extended, while samples for other experiments were immediately diluted with two parts Kenney extender (Blanchard et al. 1987) to one part semen in $50 \mathrm{ml}$ Falcon tubes. Semen was kept at ambient temperature in a polystyrene box and transported to the laboratory within $1 \mathrm{~h}$ of collection. The extended semen was subsequently fractionated on a Percoll gradient, using 40 and $80 \%$ Percoll fractions. High-quality spermatozoa were recovered from the base of the high-density region of the gradient, centrifuged (3000 g, $3 \mathrm{~min}$ ) and subsequently resuspended in BWW medium. Raw semen for proteomic analysis was also fractionated on a Percoll gradient and washed three times in BWW to isolate spermatozoa and remove residual seminal plasma. A NucleoCounter SP-100 (ChemoMetec, Allerod, Denmark) was used to determine sperm concentration. Approximately $400 \mu \mathrm{l}$ of lysis buffer (4\% Chaps, $7 \mathrm{M}$ urea and $2 \mathrm{M}$ thiourea in water) were added to $100 \times 10^{6} \mathrm{sperm} / \mathrm{ml}$ in Eppendorf tubes for $1 \mathrm{~h}$ at $4{ }^{\circ} \mathrm{C}$ with constant rotation. Samples were centrifuged $(10000 \mathrm{~g}, 15 \mathrm{~min})$ and the supernatant transferred to new tubes. Protein estimation was subsequently performed using a 2D quant kit (G.E. Healthcare, Castle Hill, NSW, Australia). Approximately 400-500 $\mu \mathrm{g}$ of protein per sample were precipitated using methanol/chloroform as described previously (Baker et al. 2004).

\section{Electrophoresis and preparation of tryptic digests}

SDS-PAGE was conducted on solubilised sperm proteins in 4-20\% polyacrylamide gels, using standard methods. Gels were silver stained as described previously (Shevchenko et al. 1996) and fractionated by dissecting each gel lane into 48 uniform bands. Individual polyacrylamide gel plugs were destained with $15 \mathrm{mM}$ potassium ferricyanide/50 $\mathrm{mM}$ sodium thiosulphate and washed four times with $25 \mathrm{mM}$ ammonium bicarbonate in $50 \%$ methanol. After reduction (dithiothreitol, $10 \mathrm{mM}, 1 \mathrm{~h}$ at $22^{\circ} \mathrm{C}$ ) and alkylation (iodoacetamide, $55 \mathrm{mM}$, $45 \mathrm{~min}$ at $\left.22^{\circ} \mathrm{C}\right)$, gel plugs were dehydrated in acetonitrile $(\mathrm{ACN})$, reconstituted with $50 \mathrm{mM}$ ammonium bicarbonate containing $100 \mathrm{ng}$ of trypsin (Promega) and incubated at room temperature overnight. The resulting peptides were extracted by application of $50 \%$ ACN $/ 0.1 \%$ trifluoroacetic acid and then $100 \%$ ACN $/ 0.1 \%$ trifluoroacetic acid, and the extracts were combined. Extracts were dried by centrifugal evaporation and resuspended in $15 \mu \mathrm{l} \% \mathrm{ACN} / 0.1 \%$ trifluoroacetic acid in glass vials.

\section{Mass spectrometry analyses}

Peptides generated through in-gel tryptic digestion were separated by reversed-phase nano-LC (Dionex Ultimate 3000 RSLCnano, Idstein, Germany) before being sequenced by tandem mass spectrometry (LC-MS/MS) on an electrospray ionisation 3D Ion Trap Mass Spectrometer (AmaZon ETD, Bruker Daltonik, Bremen, Germany). The raw MS/MS files were converted into MASCOT generic format and imported into Bruker's Proteinscape platform for database searching. Searches were performed using in-house licensed MASCOT server (version 2.3.02, Matrix Science, London, UK), against the SwissProt database (mammalian taxonomy) and UniprotKB (Equus caballus unreviewed taxonomy). Trypsin was selected as the digestion enzyme with up to two missed cleavages permitted. Carbamidomethylation of cysteine was set as a fixed modification, whereas oxidation of methionine and phosphorylation of serine, threonine and tyrosine were set as variable modifications. Peptide mass tolerances were set at 1.4 and 0.7 Da for parent and daughter fragment ions respectively. Peptide thresholds were set requiring a false-positive rate $<0.05 \%$ and a MASCOT score $>70$. Those spectra meeting these criteria were validated by manual inspection to ensure accurate $y$ - and b-ion detection with overlapping sequence coverage.

\section{Gene ontology analysis}

Official gene symbols obtained were used to investigate and categorise the gene ontology (GO) annotations (cellular components, molecular functions and biological processes) using DAVID (Huang da et al. 2009a,b). As the horse genome is only partially annotated, the human gene database and human 
protein orthologues were used. Protein names are listed as 'predicted', where reviewed equine annotations are not available.

\section{Sperm RNA extraction and reverse-transcriptase PCR}

Sperm RNA was prepared using Trizol reagent (Invitrogen), following the manufacturer's instructions, with addition of $5 \mu \mathrm{l}$ of $2 \mathrm{mg} / \mathrm{ml}$ glycogen (Ambion, Austin, TX, USA) at the isopropanol precipitation step to enhance RNA yield.

To confirm the presence of CPT1 isoforms in stallion spermatozoa, RNA was reverse transcribed with oligo(dT)15 primer (Promega) and M-MLV reverse transcriptase (Promega). RT-PCR was then performed to detect transcripts of CPT1A, CPT1B and CPT1C.

For the first round of $P C R$, the forward primer sequences were as follows: $5^{\prime}$-CGCCATGGATTTGCTGTACG$3^{\prime}$ (CPT1A); 5'-CTTTCTTCGTGGCCCTGGAT-3' (CPT1B) and 5'-GGTCAGTGACTGGTGGGAAG-3' (CPT1C). The reverse primer sequences were as follows: $5^{\prime}$-TTTCGTCCAGGGTCACGAAG-3' (CPT1A); 5'-AGGTGTGCTTTCATGTGGGT-3' $(C P T 1 B)$ and 5'-GCCGAGTAGCCGAGATGAAA-3' (CPT1C). These primers are predicted to generate bands of 503, 640 and $765 \mathrm{bp}$ for isoforms $1 \mathrm{a}, 1 \mathrm{~b}$ and $1 \mathrm{c}$ respectively. The PCR conditions were as follows: one cycle of $94{ }^{\circ} \mathrm{C}$ for $5 \mathrm{~min} ; 35$ cycles of $95{ }^{\circ} \mathrm{C}$ for $45 \mathrm{~s}, 59^{\circ} \mathrm{C}$ for $45 \mathrm{~s}\left(65^{\circ} \mathrm{C}\right.$ for $45 \mathrm{~s}$ in the case of $C P T 1 A$ ) and $72{ }^{\circ} \mathrm{C}$ for 2 min and one cycle of $72{ }^{\circ} \mathrm{C}$ for $10 \mathrm{~min}$. For nested PCR, a 1:100 dilution of the first round product was used as the template and the conditions were the same as mentioned earlier in this study.

For nested PCR, the forward primer sequences were as follows: 5'-CGCCATCCTGCTCTACAGAC-3' (CPT1A); 5'-GGCACTGCATAGGCAAATCG-3' (CPT1B) and 5'-CAGCAGTTCCAGCGAATCCT-3' (CPT1C). The reverse primer sequences were as follows: $5^{\prime}$-GACGGGTCGTCCAAAATCCT-3' (CPT1A); 5'-CTGGTCCGGCACTTCTTGAT-3' (CPT1B) and 5'-ATTTGTCAAACCAGCGGTCG-3' (CPT1C). These primers are predicted to generate bands of 282, 190 and $280 \mathrm{bp}$ for isoforms $1 \mathrm{a}, 1 \mathrm{~b}$ and $1 \mathrm{c}$ respectively.

The PCR products were run on $1 \%$ agarose gels and the DNA was purified from the gel using the Wizard Gel Clean-Up Kit (Promega). The DNA was sequenced at the Australian Genomic Research Facility (Sydney).

\section{Inhibition of sperm $\beta$-oxidation}

In order to ascertain whether enzymes involved in $\beta$-oxidation of fatty acids are indeed functional in stallion spermatozoa, we incubated sperm samples with etomoxir, a selective inhibitor of CPT1, the rate-limiting enzyme of $\beta$-oxidation.

Stallion sperm from at least three ejaculates of three stallions, extended with Kenney extender and prepared on Percoll gradient (as described above), were resuspended at a concentration of $2 \times 10^{7} \mathrm{sperm} / \mathrm{ml}$ and treatments set up as follows: BWW only, BWW with etomoxir $(10 \mu \mathrm{M})$ and BWW with etomoxir $(100 \mu \mathrm{M})$. Samples were incubated at $37^{\circ} \mathrm{C}$, with motility measurements recorded at 1 and $24 \mathrm{~h}$ of incubation and vitality assessed at $24 \mathrm{~h}$.

\section{Sperm motility analysis}

Sperm motility was objectively determined using computerassisted sperm analysis (CASA; IVOS, Hamilton Thorne, Danvers, MA, USA) using the following settings: negative phase-contrast optics, recording rate of 60 frames/s, minimum contrast of 70 , minimum cell size of four pixels, low-size gate of 0.17 , high-size gate of 2.9, low-intensity gate of 0.6 , high-intensity gate of 1.74 , non-motile head size of ten pixels, non-motile head intensity of 135 , progressive average path velocity (VAP) threshold of $50 \mu \mathrm{m} / \mathrm{s}$, slow (static) cell VAP threshold of $20 \mu \mathrm{m} / \mathrm{s}$, slow (static) cell VSL threshold of $0 \mu \mathrm{m} / \mathrm{s}$, and threshold STR of $75 \%$. Cells exhibiting a VAP of $\geq 50 \mu \mathrm{m} / \mathrm{s}$ and a STR of $\geq 75$ were considered progressive. A minimum of 200 spermatozoa in five fields were assessed using $20 \mu \mathrm{m}$ Leja standard count slides (Gytech, Armdale North, Victoria, Australia) and a stage temperature of $37^{\circ} \mathrm{C}$.

\section{Flow cytometry and vitality assessment}

Flow cytometry was performed using a FACSCalibur flow cytometer (Becton Dickinson, Franklin Lakes, NJ, USA) with a $488 \mathrm{~nm}$ argon ion laser. Emission measurements were made using 530/30 band pass (green/FL-1), 585/42 band pass (red/FL-2), 661/16 band pass (red/FL-4) and $>670$ long pass (far red/FL-3) filters. Debris was gated out using a forward scatter/side scatter dot plot, and 5000 cells were analysed per sample. All data were analysed using the CellQuest Pro software (Becton Dickinson).

Sperm vitality was assessed using LIVE/DEAD stain (Molecular Probes, Australia). Two million spermatozoa from each sample were incubated at $37^{\circ} \mathrm{C}$ for $20 \mathrm{~min}$ with reconstituted stain (as per manufacturer's instructions) at a concentration of $1 \mu \mathrm{l} / \mathrm{ml}$. Spermatozoa were washed once and resuspended in modified BWW. Samples were analysed by flow cytometry and classified as either vital or non-vital.

\section{Results}

\section{Protein identification, annotation and $G O$}

Data obtained by LC-MS/MS and subsequent database analyses identified 9883 peptides, constituting 1030 proteins with MASCOT scores over 70. Out of these, 975 were matched with gene names. These were used to obtain theoretical GO classifications, represented in Fig. 1.

Classification according to biological process revealed the dominant categories to be those associated with metabolism, with proteins involved in cellular metabolic processes forming the single largest group (372 of 895 genes classified), followed by establishment of localisation (161) and transport (158). Proteins were distributed among the major energy production pathways as follows: oxidative phosphorylation (33 proteins), glycolysis (25 proteins) and fatty acid metabolism (25 proteins).

Cell compartment analysis associated a large number of proteins with the mitochondrion (203 of 655), with the cytosol, envelope and cytoskeleton categories also 


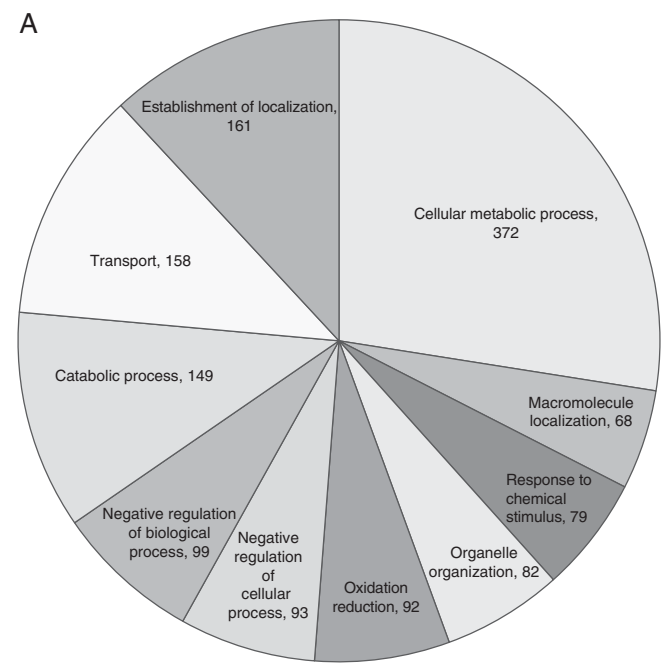

B

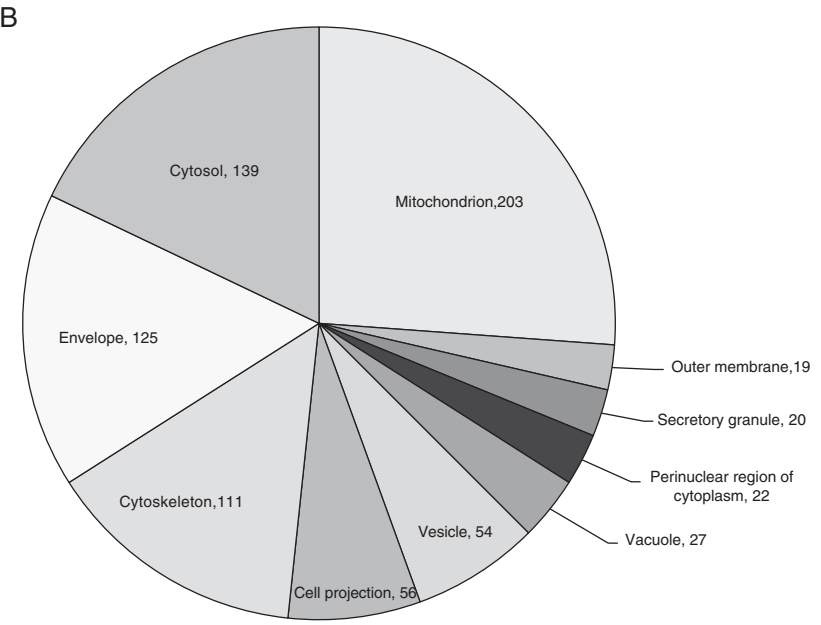

C

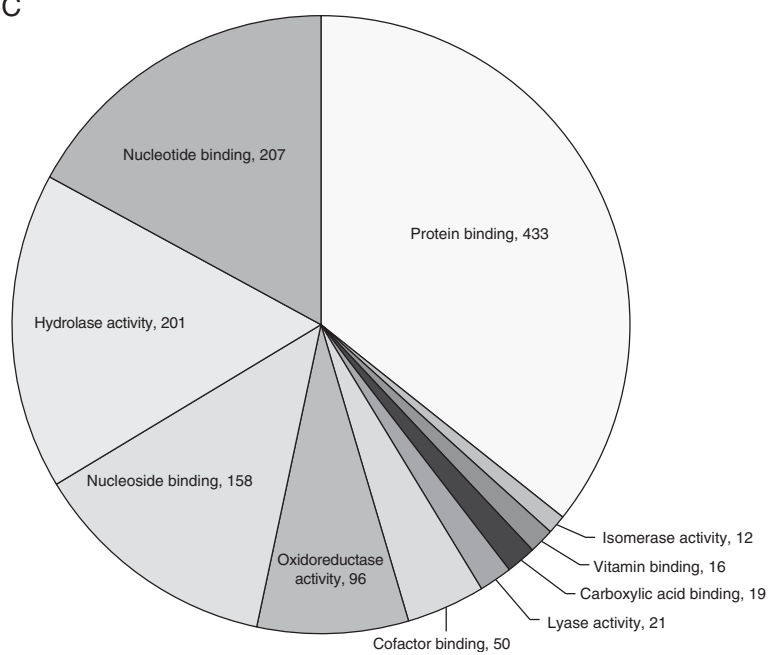

Figure 1 Gene ontology classification of gene products identified in stallion sperm proteome, according to analysis with DAVID Bioinformatics. Ten of the most highly represented categories are shown for biological process (A), cellular compartment (B) and molecular function $(\mathrm{C})$. strongly represented $(139,125$ and 111 gene products respectively).

Analysis of the molecular function of the proteome showed protein binding to potentially involve 433 out of 633 successfully classified proteins. Nucleotide and nucleoside binding (207 and 158 proteins respectively), as well as hydrolase activity (201 proteins), comprised the other major functional groups.

The full list of proteins, genes and accession number information is provided as Supplementary Table 1, see section on supplementary data given at the end of this article. A list of proteins of interest, selected according to their potential roles in metabolism, response to oxidative damage, receptor activity and sperm antigenicity is given in Table 1. This includes key enzymes involved in $\beta$-oxidation of fatty acids, several components of the thioredoxin-peroxiredoxin system, 19 receptors or receptor-associated proteins and several antigenic proteins implicated in immune infertility and development of mammalian immunocontraceptives.

\section{Detection of CPT1 isoforms in spermatozoa}

Nested RT-PCR demonstrated the presence of all three isoforms of CPT1 (CPT1A, CPT1B and CPT1C). Positive staining of bands on ethidium bromide-stained gels (Fig. 2) was evident at the expected bp numbers (282, 190 and $280 \mathrm{bp}$ respectively). Sequencing of DNA confirmed that the bands correspond with the respective CPT1 isoform sequences.

\section{Sperm motility and vitality after inhibition of $\beta$-oxidation}

As a number of key enzymes of $\beta$-oxidation were identified to be present in stallion spermatozoa, further in vitro assays were set up to test whether $\beta$-oxidation of fatty acids does indeed contribute to the energy demands of stallion spermatozoa.

The results of a CASA analysis of sperm movement characteristics in the presence of an inhibitor of fatty acid metabolism, etomoxir, are shown in Fig. 3. No significant differences between treatments in motility percentages were observed after $1 \mathrm{~h}$ of incubation. However, incubation with $100 \mu \mathrm{M}$ etomoxir was associated with a slight but significant decrease in $\operatorname{VAP}(P<0.05)$.

After $24 \mathrm{~h}$ of incubation, a dose-dependent decrease in overall motility became apparent. Total motility (TM) and rapid motility (RM) were significantly decreased by treatment with 1,10 and $100 \mu \mathrm{M}$ etomoxir (TM: $P<0.01$, $P<0.01$ and $P<0.001$ respectively; RM: $P<0.05$, $P<0.01$ and $P<0.001$ respectively), while progressive motility was decreased by treatment with 10 and $100 \mu \mathrm{M}$ etomoxir $(P<0.05$ and $P<0.01$ respectively). A highly significant decrease in VAP was also associated with $100 \mu \mathrm{M}$ etomoxir treatment $(P<0.001)$. 
Table 1 Proteins of interest identified by LC-MS/MS and gene ontology analysis of equine (Equus caballus) spermatozoa.

\begin{tabular}{|c|c|c|c|c|}
\hline & Gene & Score & MW (kDa) & Peptides \\
\hline \multicolumn{5}{|l|}{ Proteins involved in $\beta$-oxidation of fatty acids } \\
\hline Acyl-coenzyme A dehydrogenase, very long chain & $A C A D V L$ & 1722.4 & 69.9 & 31 \\
\hline Acyl-coenzyme A dehydrogenase, C-4 to C-12 straight chain & ACADM & 1022.6 & 45.4 & 20 \\
\hline Electron-transferring-flavoprotein dehydrogenase & ETFDH & 404.9 & 68.5 & 7 \\
\hline Enoyl coenzyme A hydratase, short chain, 1, mitochondrial & ECHS1 & 425.1 & 28.6 & 7 \\
\hline Carnitine acetyltransferase & CRAT & 827.8 & 69.7 & 16 \\
\hline $\begin{array}{l}\text { Hydroxyacyl-coenzyme A dehydrogenase/3-ketoacyl-coenzyme A thiolase/enoyl-coenzyme } \\
\text { A hydratase (trifunctional protein), } \alpha \text { subunit }\end{array}$ & $H A D H A$ & 1809.6 & 82.6 & 32 \\
\hline $\begin{array}{l}\text { Hydroxyacyl-coenzyme A dehydrogenase/3-ketoacyl-coenzyme A thiolase/enoyl-coenzyme } \\
\text { A hydratase (trifunctional protein), } \beta \text { subunit }\end{array}$ & $H A D H B$ & 989.3 & 51.1 & 18 \\
\hline Enoyl coenzyme A hydratase domain containing 1 (fragment) & ECHDC1 & 153.9 & 33.7 & 1 \\
\hline Enoyl-CoA delta isomerase 1 (fragment) & ECl1 & 108.6 & 27.5 & 1 \\
\hline Propionyl coenzyme A carboxylase, $\alpha$ polypeptide (fragment) & PCCA & 220.5 & 70.6 & 4 \\
\hline Propionyl coenzyme A carboxylase, $\beta$ polypeptide (fragment) & $P C C B$ & 120 & 59.0 & 2 \\
\hline \multicolumn{5}{|l|}{ Proteins involved in response to oxidative damage } \\
\hline Clusterin precursor & CLU & 322.7 & 52.1 & 5 \\
\hline Excision repair cross-complementing rodent repair deficiency, complementation group 6 & ERCC6 & 240.6 & 163.8 & 4 \\
\hline Electron-transferring-flavoprotein dehydrogenase & ETFDH & 404.9 & 68.5 & 7 \\
\hline Phospholipid hydroperoxide glutathione peroxidase, mitochondrial & GPX4 & 549 & 22.2 & 11 \\
\hline Isocitrate dehydrogenase (NADP) & IDH1 & 429.8 & 47.6 & 9 \\
\hline Lon protease homolog & LONP1 & 816.9 & 96.7 & 15 \\
\hline NADH dehydrogenase (ubiquinone) $1 \propto$ subcomplex, 12 & NDUFA12 & 225.3 & 17.5 & 4 \\
\hline NADH dehydrogenase (ubiquinone) $1 \alpha$ subcomplex, $6,14 \mathrm{kDa}$ & NDUFA6 & 112.4 & 16.5 & 2 \\
\hline NADH dehydrogenase (ubiquinone) $1 \beta$ subcomplex, $4,15 \mathrm{kDa}$ & NDUFB4 & 173.1 & 15.3 & 3 \\
\hline NADH dehydrogenase (ubiquinone) Fe-S protein 2, 49 kDa (NADH-coenzyme Q reductase) & NDUFS2 & 457 & 52.4 & 10 \\
\hline NADH dehydrogenase (ubiquinone) Fe-S protein 8, $23 \mathrm{kDa}$ (NADH-coenzyme Q reductase) & NDUFS8 & 88 & 23.7 & 1 \\
\hline Parkinson disease (autosomal recessive, early onset) 7 & PARKT & 605.4 & 19.9 & 11 \\
\hline Phosphatidylethanolamine binding protein 1 & PEBP1 & 598 & 21.3 & 9 \\
\hline Peroxiredoxin 5 & PRDX5 & 1241.4 & 17.0 & 20 \\
\hline Peroxiredoxin 6 & PRDX6 & 601.5 & 25.1 & 11 \\
\hline Proteasome subunit $\beta$ type & PSMB5 & 301.1 & 28.8 & 7 \\
\hline Superoxide dismutase 1 (Cu-Zn) & SOD1 & 326.7 & 16.1 & 6 \\
\hline Superoxide dismutase 2 & SOD2 & 469 & 24.3 & 7 \\
\hline Thioredoxin reductase 1 & $T X N R D 1$ & 308.4 & 56.3 & 4 \\
\hline Thioredoxin reductase 2 & TXNRD2 & 351.6 & 53.2 & 6 \\
\hline \multicolumn{5}{|l|}{ Receptors and receptor-associated proteins } \\
\hline Adrenergic, $\beta$, receptor kinase 2 & $A D R B K 2$ & 97.9 & 75.1 & 1 \\
\hline Anthrax toxin receptor-like & ANTXRL & 108.1 & 29.9 & 3 \\
\hline G protein-coupled receptor, family $\mathrm{C}$, group 5 , member $\mathrm{A}$ & GPRC5A & 70.8 & 39.8 & 2 \\
\hline Interleukin 31 receptor $A$ & IL31RA & 164.1 & 83.0 & 2 \\
\hline Mannose-6-phosphate receptor binding protein 1 & PLIN3 & 356.8 & 39.9 & 4 \\
\hline NMDA receptor regulated 2 & ICE2 & 174.2 & 107.6 & 4 \\
\hline Nuclear receptor co-repressor 1 & NCOR1 & 210.9 & 269.9 & 4 \\
\hline Nuclear receptor interacting protein 1 & NRIP1 & 148.3 & 126.5 & 5 \\
\hline Polymeric immunoglobulin receptor & PIGR & 964.1 & 83.0 & 11 \\
\hline Protein tyrosine phosphatase, receptor type, G & PTPRG & 119.1 & 154.5 & 2 \\
\hline Receptor accessory protein 3 & REEP3 & 116 & 27.6 & 3 \\
\hline Ryanodine receptor 3 & RYR3 & 96.4 & 551.6 & 3 \\
\hline Sortilin-related receptor precursor & SORL 1 & 121.2 & 247.6 & 3 \\
\hline Sphingosine-1-phosphate receptor 4 & S1PR4 & 88.2 & 41.7 & 3 \\
\hline Thyroid hormone receptor interactor 11 & TRIP11 & 345.6 & 227.4 & 3 \\
\hline TNF receptor-associated factor 3 & TRAF3 & 96.8 & 64.5 & 2 \\
\hline TNF receptor-associated protein 1 & TRAP1 & 565 & 77.2 & 7 \\
\hline Toll-like receptor 8 & TLR8 & 206.4 & 120.2 & 2 \\
\hline Tyrosine-protein kinase receptor & INSR & 96.8 & 155.1 & 3 \\
\hline \multicolumn{5}{|l|}{ Proteins involved in anti-sperm immune infertility and contraceptive vaccine targets } \\
\hline Sperm associated antigen 17 & SPAG17 & 514.6 & 248.9 & 12 \\
\hline Sperm associated antigen 6 & SPAG6 & 1376 & 50.8 & 26 \\
\hline Sperm associated antigen 16 & SPAG16 & 280.1 & 63.9 & 8 \\
\hline Sperm acrosome associated 3 & SPACA3 & 457.8 & 21.2 & 8 \\
\hline Glyceraldehyde-3-phosphate dehydrogenase & GAPDHS & 5525.3 & 43.4 & 88 \\
\hline Adenylate kinase 8 & AK8 & 685.2 & 39.3 & 14 \\
\hline ADAM metallopeptidase domain 2 & ADAM2 & 587.8 & 82.1 & 8 \\
\hline Sperm surface protein Sp17 & SPA17 & 291.5 & 17.1 & 6 \\
\hline Izumo sperm-egg fusion 1 & IZUMO1 & 1231.5 & 34.8 & 24 \\
\hline Lactate dehydrogenase C & $\angle D H C$ & 2489.7 & 36.0 & 45 \\
\hline Outer dense fiber of sperm tails 2 & ODF2 & 5276.4 & 99.9 & 96 \\
\hline Protein disulfide isomerase family $\mathrm{A}$, member 3 & PDIA3 & 160 & 56.6 & 4 \\
\hline Sperm flagellar 2 & SPEF2 & 779.3 & 208.6 & 19 \\
\hline
\end{tabular}



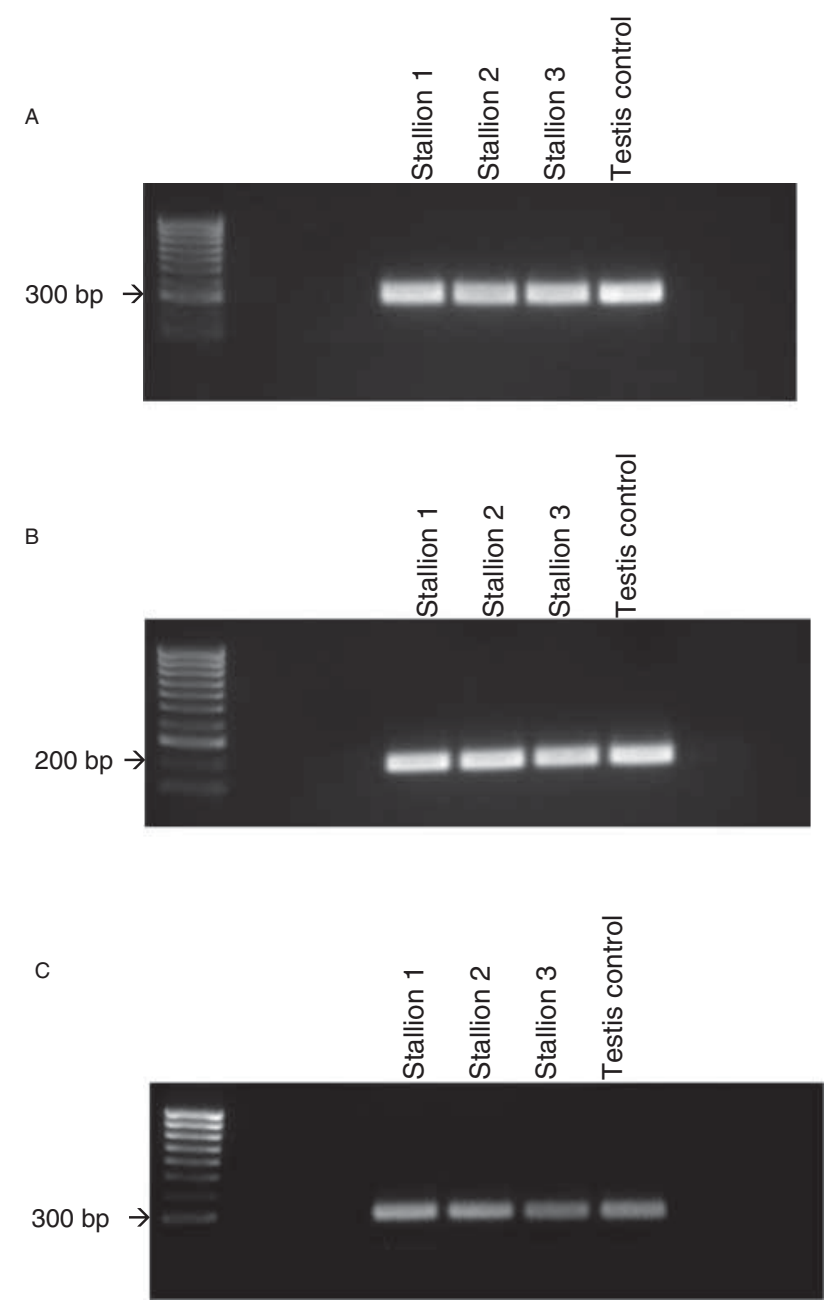

Figure 2 Ethidium bromide-stained electrophoresis gels following stallion sperm nested RT-PCR for three isoforms of CPT1: (A) showing CPT1A, (B) CPT1B and (C) CPT1C (RT, reverse transcriptase; CPT, carnitine palmitoyl transferase).

Vitality of spermatozoa after $24 \mathrm{~h}$ of incubation was not reduced by etomoxir (Fig. 3); however, sperm incubated in $10 \mu \mathrm{M}$ etomoxir displayed a small but statistically significant increase in vitality $(P<0.05)$.

\section{Discussion}

This qualitative study represents the first report of a comprehensive analysis of ejaculated stallion spermatozoa, identifying several hundred proteins that contribute to sperm structure and function. Drawing on GO data from the human proteome allowed us to predict the theoretical functions of most proteins identified and revealed new concepts relating to metabolism, antioxidant defences, receptor functions and antigenic properties of equine spermatozoa.

Theoretically, 372 of the identified proteins are involved in cellular metabolic processes; this is consistent with energy-consuming motility being a primary attribute allowing sperm to reach their target destination and achieve fertilisation. More surprising is the finding that the three major metabolic processes - glycolysis, oxidative phosphorylation and fatty acid metabolism - are distributed evenly in terms of their protein representation. Moreover, the major mitochondrial fatty acid metabolism pathway of $\beta$-oxidation was represented by 11 proteins (Table 1 ). Of course, the active roles of these enzymes in metabolism are putative; the presence of enzymes belonging to a metabolic pathway does not confirm that this pathway is truly active in a live sperm cell. For this reason, after confirmation of sperm CPT1 by RT-PCR, we investigated the contribution of fatty acid $\beta$-oxidation to sperm motility and survival using treatment of stallion sperm with a $\beta$-oxidation inhibitor, etomoxir. This compound irreversibly binds CPT1, an enzyme necessary for transport of long-chain fatty acids into the mitochondrial matrix and hence for mitochondrial $\beta$-oxidation. A dose-dependent negative effect of this treatment on sperm motility, without any decrease in vitality, suggests that energy produced by sperm via fatty acid oxidation pathways contributes to the maintenance of motility. Hence, the $\beta$-oxidation enzymes identified in the sperm proteome appear to be functional and not merely a vestige of the cells' metabolic activity during spermatogenesis.

Fatty acid levels, both as endogenous sperm plasma membrane components (Garcia et al. 2011, Macias Garcia et al. 2011) and when supplemented in sperm media (Dixon \& Kreider 1981), have been positively correlated with sperm quality in the stallion. The mechanisms driving this correlation are a subject of debate, especially as the inverse of this relationship has been observed for human spermatozoa (Ollero et al. 2001, Khosrowbeygi \& Zarghami 2007) and negative effects of polyunsaturated fatty acids have been attributed to the high susceptibility of these molecules to peroxidation, predisposing sperm to oxidative stress and the subsequent loss of functional competence (Aitken et al. 2006).

While the positive effects of fatty acids on stallion sperm quality may be partially driven by their role in maintaining plasma membrane fluidity, our results indicate that fatty acids are also a potentially important substrate for production of energy via $\beta$-oxidation. If sperm are able to effectively utilise fatty acids as an energy source supporting motility, the formulation of fatty acid components of sperm storage media may need to be revisited. Furthermore, strategies diverting sperm metabolism towards fatty acid oxidation may prove advantageous for prolonging in vitro sperm storage, as this type of metabolism is more conducive to long-term, sustained release of energy, such as that observed in the tissues of hibernating animals (Wakil \& Abu-Elheiga 2009).

GO analysis for biological process identified 20 proteins potentially involved in responding to oxidative stress, as listed in Table 1. Out of these, glutathione 
peroxidase and superoxide dismutase are welldocumented reactive oxygen species (ROS) scavengers although their activity appears minimal in equine
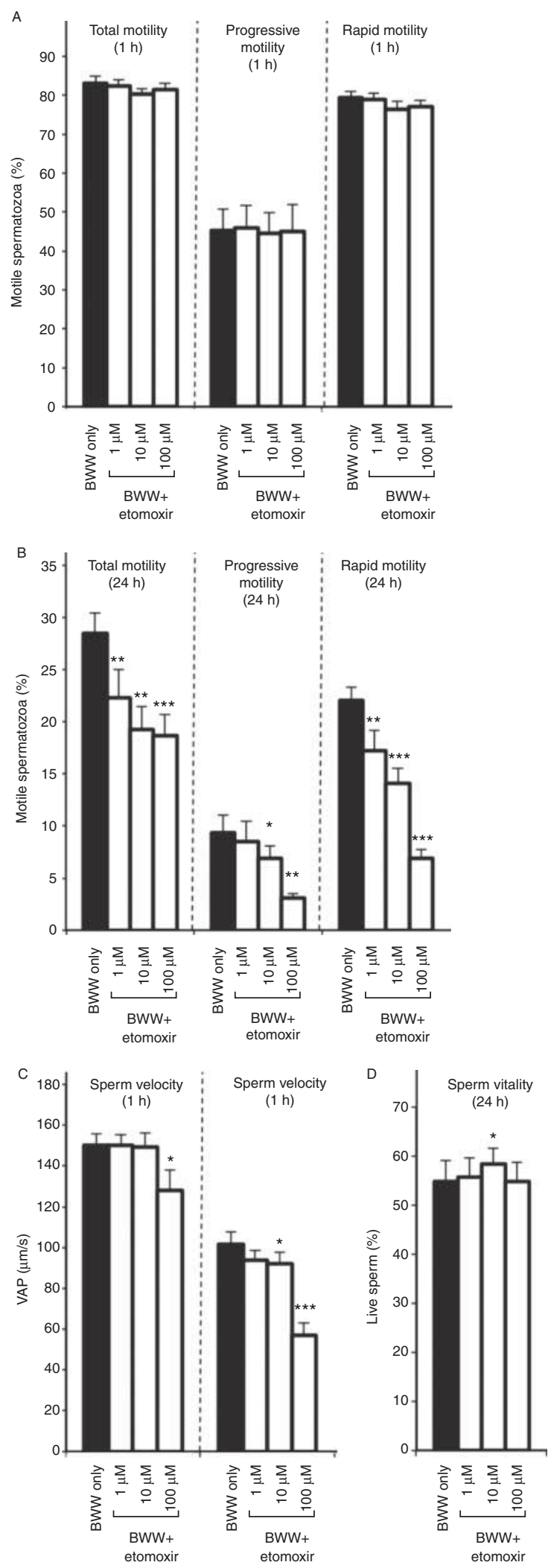

spermatozoa themselves (Baumber \& Ball 2005). Seminal plasma is considered to be the main source of antioxidant support for ejaculated spermatozoa, yet stallion sperm appear to be rather resilient to the debilitating effects of ROS even in the absence of seminal plasma (Gibb et al. 2014). This points to an alternative, intracellular mechanism of defence against oxidative damage. We identified four members of the thioredoxin/peroxiredoxin system: peroxiredoxins 5 and 6 (PRDX5 and PRDX6) and two mitochondrial thioredoxin reductases (TXNRD1 and TXNRD2). This group of enzymes represents a major redox homoeostasis mechanism in somatic cells (Fourquet et al. 2008), and its role is now beginning to be recognised in sperm ROS defence (Manandhar et al. 2009). Peroxiredoxins (including PRDX5 and PRDX6) have been recently confirmed to be present in human spermatozoa and shown to be potentially capable of protecting the cells from peroxide radical damage (O'Flaherty \& de Souza 2011, Gong et al. 2012). Furthermore, a knockout mouse lacking the sperm-specific thioredoxins, Txndc2 and Txndc3 (Nme8), has been generated and shown to result in age-dependent changes in the spermatozoa associated with accelerated motility loss, high rates of DNA damage, increases in ROS generation, enhanced formation of lipid aldehyde-protein adducts and impaired protamination of the sperm chromatin (Smith et al. 2013). This, together with localisation of PRDX5 to the mitochondrial sheath in human spermatozoa (O'Flaherty \&de Souza 2011), leads us to propose that the thioredoxin/peroxiredoxin system may serve as a strategic antioxidative mechanism in equine spermatozoa: cells relying heavily on mitochondria for energy metabolism, and therefore producing high levels of ROS, have a good reason to position their oxidation defences close to the site of ROS release and thus avoid downstream oxidative damage.

Further GO analysis of biological processes represented in stallion spermatozoa revealed 79 proteins potentially involved in response to chemical stimuli and, among these, numerous receptor molecules. Of the 19 receptors and receptor-associated proteins identified (Table 1), two have not been previously associated with spermatozoa in the published literature: G protein-coupled receptor C5A (GPRC5A) and polymeric immunoglobulin receptor (PigR).

Figure 3 Inhibition of fatty acid $\beta$-oxidation in stallion spermatozoa by etomoxir reduces sperm motility but not vitality. Total, progressive and rapid motility for spermatozoa incubated at $37^{\circ} \mathrm{C}$ with $0,1,10$ and $100 \mu \mathrm{M}$ etomoxir, measured using CASA at $1 \mathrm{~h}(\mathrm{~A})$ and $24 \mathrm{~h}(\mathrm{~B})$, are shown. Average path velocity measurements are shown in $(C)$ and vitality after $24 \mathrm{~h}$ of incubation, measured using LIVE/DEAD stain and flow cytometry, is shown in (D) (bars indicate s.E.M.; asterisks indicate difference between control (BWW alone) and samples treated with etomoxir according to Student's $t$-test: ${ }^{*} P<0.05,{ }^{* *} P<0.01$, ${ }^{* * *} P<0.001 ; n=9$. CASA, computer-assisted sperm analysis). 
GPRC5A, also known as retinoic acid-induced protein 3 , is a receptor of currently unknown function, with no defined natural ligand. To date, it has been suggested as a tumour-suppressing protein (Tao et al. 2007) and has been shown to be involved in CAMP signalling and possibly regulation of apoptosis (Hirano et al. 2006); thus, it may have important implications for survival and capacitation of equine sperm.

PigR is a transmembrane protein normally responsible for transcytosis of immunoglobulins (IgA) across epithelial cells lining mucosal surfaces (Kaetzel 2005). A spermatozoon would have no obvious use for such a transfer mechanism. Anti-sperm IgA can be secreted in both the female and male reproductive tracts leading to infertility (Bohring \& Krause 2005, Francavilla et al. 2007); however, anti-sperm antibodies have been detected in seminal plasma of up to $62 \%$ of fertile men (Paradisi et al. 1995) and in cervico-vaginal secretions of a small percentage of fertile women (Mahdi et al. 2011). If confirmed to be present and indeed a functional receptor in sperm, it is possible that PigR mediates the interaction between spermatozoa and low levels of secreted IgA encountered en route to fertilisation; the significance of such an interaction is not clear at the present time.

At least 13 of the identified stallion sperm proteins have been implicated in immunoinfertility via production of anti-sperm antibodies in various species, by spontaneous or experimental means (Table 1). Detection of the proteins IZUMO1, LDHC, fertilin- $\beta$ (ADAM2) and sperm flagellar protein (SPEF2) in this study presents an exciting finding as these antigens have all undergone degrees of assessment as immunocontraceptive vaccine targets (Chen et al. 2008, Naz 2008, Wang et al. 2009, Sun et al. 2010, Khan et al. 2011). Antibodies to adenylate kinase (AK8) and sperm protein 17 (SPA17) proteins also identified presently - have been detected in sera of immunoinfertile men (Bhande \& Naz 2007, Zhang et al. 2007) and have also been suggested as potential antifertility targets. Identification of these antigenic sperm proteins, currently being considered in vertebrate species as targets for contraceptive vaccines, is an encouraging step towards development of novel methods of fertility control for feral and wild horse populations. Further analyses of the newly obtained sperm proteome will probably reveal additional spermspecific, functional proteins that can be targeted by fertility vaccines.

\section{Conclusion}

Proteomic investigation of ejaculated stallion spermatozoa allowed for identification of over a thousand proteins represented by 975 genes. While the individual functional significance of each family of proteins is yet to be demonstrated directly, GO analysis and inspection of proteins of interest are already providing new insights into stallion sperm metabolism, antioxidant defence function, receptor activity and antigenicity.

\section{Supplementary data}

This is linked to the online version of the paper at http://dx.doi. org/10.1530/REP-14-0500.

\section{Declaration of interest}

The authors declare that there is no conflict of interest that could be perceived as prejudicing the impartiality of the research reported.

\section{Funding}

This work was supported by the Australian Research Council in conjunction with Harness Racing Australia and Hunter Thoroughbred Breeders Association (Linkage Grant LP1201 00219), and the Invasive Animals Cooperative Research Centre.

\section{References}

Aitken RJ, Wingate JK, De Iuliis GN, Koppers AJ \& McLaughlin EA 2006 Cis-unsaturated fatty acids stimulate reactive oxygen species generation and lipid peroxidation in human spermatozoa. Journal of Clinical Endocrinology and Metabolism 91 4154-4163. (doi:10.1210/jc.20061309)

Amaral A, Castillo J, Ramalho-Santos J \& Oliva R 2014 The combined human sperm proteome: cellular pathways and implications for basic and clinical science. Human Reproduction Update 20 40-62. (doi:10. 1093/humupd/dmt046)

Baker MA, Lane DJ, Ly JD, De Pinto V \& Lawen A 2004 VDAC1 is a transplasma membrane NADH:ferricyanide reductase. Journal of Biological Chemistry 279 4811-4819. (doi:10.1074/jbc.M311020200)

Baker MA, Reeves G, Hetherington L, Muller J, Baur I \& Aitken RJ 2007 Identification of gene products present in Triton X-100 soluble and insoluble fractions of human spermatozoa lysates using LC-MS/MS analysis. Proteomics. Clinical Applications 1 524-532. (doi:10.1002/ prca.200601013)

Baker MA, Hetherington L, Reeves GM \& Aitken RJ 2008a The mouse sperm proteome characterized via IPG strip prefractionation and LCMS/MS identification. Proteomics 8 1720-1730. (doi:10.1002/pmic. 200701020)

Baker MA, Hetherington L, Reeves G, Muller J \& Aitken RJ 2008b The rat sperm proteome characterized via IPG strip prefractionation and LCMS/MS identification. Proteomics 8 2312-2321. (doi:10.1002/pmic. 200700876)

Baker MA, Nixon B, Naumovski N \& Aitken RJ 2012 Proteomic insights into the maturation and capacitation of mammalian spermatozoa. Systems Biology in Reproductive Medicine 58 211-217. (doi:10.3109/ 19396368.2011.639844)

Ball BA 2008 Diagnostic methods for evaluation of stallion subfertility: a review. Journal of Equine Veterinary Science 28 650-665. (doi:10.1016/ j.jevs.2008.10.003)

Baumber J \& Ball BA 2005 Determination of glutathione peroxidase and superoxide dismutase-like activities in equine spermatozoa, seminal plasma, and reproductive tissues. American Journal of Veterinary Research 66 1415-1419. (doi:10.2460/ajvr.2005.66.1415)

Bhande S \& Naz RK 2007 Molecular identities of human sperm proteins reactive with antibodies in sera of immunoinfertile women. Molecular Reproduction and Development 74 332-340. (doi:10.1002/mrd.20643)

Blanchard TL, Varner DD, Love CC, Hurtgen JP, Cummings MR \& Kenney RM 1987 Use of a semen extender containing antibiotic to 
improve the fertility of a stallion with seminal vesiculitis due to Pseudomonas aeruginosa. Theriogenology 28 541-546. (doi:10.1016/ 0093-691X(87)90259-7)

Bohring C \& Krause W 2005 The role of antisperm antibodies during fertilization and for immunological infertility. Chemical Immunology and Allergy 88 15-26. (doi:10.1159/000087818)

Byrne K, Leahy T, McCulloch R, Colgrave ML \& Holland MK 2012 Comprehensive mapping of the bull sperm surface proteome. Proteomics 12 3559-3579. (doi:10.1002/pmic.201200133)

Chen Y, Zhang D, Xin N, Xiong Y, Chen P, Li B, Tu X \& Lan F 2008 Construction of sperm-specific lactate dehydrogenase DNA vaccine and experimental study of its immunocontraceptive effect on mice. Science in China. Series C, Life Sciences 51 308-316. (doi:10.1007/s11427-0080035-7)

Cornwall GA 2014 Role of posttranslational protein modifications in epididymal sperm maturation and extracellular quality control. Advances in Experimental Medicine and Biology 759 159-180. (doi:10.1007/978-1-4939-0817-2_8)

Dacheux JL \& Dacheux F 2014 New insights into epididymal function in relation to sperm maturation. Reproduction 147 R27-R42. (doi:10.1530/ REP-13-0420)

Dias GM, López ML, Ferreira ATS, Chapeaurouge DA, Rodrigues A, Perales J \& Retamal CA 2014 Thiol-disulfide proteins of stallion epididymal spermatozoa. Animal Reproduction Science 145 29-39. (doi:10.1016/j.anireprosci.2013.12.007)

Dixon KE \& Kreider JL 1981 Effect of calcium and fatty acids on the isolation of stallion spermatozoa in BSA. Theriogenology 15 335-344. (doi:10.1016/0093-691X(81)90001-7)

Fouchecourt S, Metayer S, Locatelli A, Dacheux F \& Dacheux JL 2000 Stallion epididymal fluid proteome: qualitative and quantitative characterization; secretion and dynamic changes of major proteins. Biology of Reproduction 62 1790-1803. (doi:10.1095/biolreprod62. 6.1790)

Fourquet S, Huang ME, D'Autreaux B \& Toledano MB 2008 The dual functions of thiol-based peroxidases in $\mathrm{H}_{2} \mathrm{O}_{2}$ scavenging and signaling. Antioxidants \& Redox Signaling 10 1565-1576. (doi:10.1089/ars.2008. 2049)

Francavilla F, Santucci R, Barbonetti A \& Francavilla S 2007 Naturallyoccurring antisperm antibodies in men: interference with fertility and clinical implications. An update. Frontiers in Bioscience 12 2890-2911. (doi:10.2741/2280)

Gadella BM 2008 Sperm membrane physiology and relevance for fertilization. Animal Reproduction Science 107 229-236. (doi:10. 1016/j.anireprosci.2008.05.006)

Galli C, Duchi R, Colleoni S, Lagutina I \& Lazzari G 2014 Ovum pick up, intracytoplasmic sperm injection and somatic cell nuclear transfer in cattle, buffalo and horses: from the research laboratory to clinical practice. Theriogenology 81 138-151. (doi:10.1016/j.theriogenology. 2013.09.008)

Gamboa S \& Ramalho-Santos J 2005 SNARE proteins and caveolin-1 in stallion spermatozoa: possible implications for fertility. Theriogenology 64 275-291. (doi:10.1016/j.theriogenology.2004.11.021)

Garcia BM, Fernandez LG, Ferrusola CO, Salazar-Sandoval C, Rodriguez AM, Martinez HR, Tapia JA, Morcuende D \& Pena FJ 2011 Membrane lipids of the stallion spermatozoon in relation to sperm quality and susceptibility to lipid peroxidation. Reproduction in Domestic Animals 46 141-148. (doi:10.1111/j.1439-0531.2010.01609.x)

Gibb Z, Lambourne SR \& Aitken RJ 2014 The paradoxical relationship between stallion fertility and oxidative stress. Biology of Reproduction 91 77. (doi:10.1095/biolreprod.114.118539)

Gong S, San Gabriel MC, Zini A, Chan P \& O'Flaherty C 2012 Low amounts and high thiol oxidation of peroxiredoxins in spermatozoa from infertile men. Journal of Andrology 33 1342-1351. (doi:10.2164/jandrol.111. 016162)

Hirano M, Zang LQ, Oka T, Ito Y, Shimada Y, Nishimura Y \& Tanaka T 2006 Novel reciprocal regulation of cAMP signaling and apoptosis by orphan G-protein-coupled receptor GPRC5A gene expression. Biochemical and Biophysical Research Communications 351 185-191. (doi:10.1016/ j.bbrc.2006.10.016)

Huang da W, Sherman BT \& Lempicki RA 2009a Bioinformatics enrichment tools: paths toward the comprehensive functional analysis of large gene lists. Nucleic Acids Research 37 1-13. (doi:10.1093/nar/gkn923)
Huang da W, Sherman BT \& Lempicki RA 2009b Systematic and integrative analysis of large gene lists using DAVID bioinformatics resources. Nature Protocols 4 44-57. (doi:10.1038/nprot.2008.211)

Kaetzel CS 2005 The polymeric immunoglobulin receptor: bridging innate and adaptive immune responses at mucosal surfaces. Immunological Reviews 206 83-99. (doi:10.1111/j.0105-2896.2005.00278.x)

Khan SA, Jadhav SV, Suryawanshi AR, Bhonde GS, Gajbhiye RK \& Khole VV 2011 Evaluation of contraceptive potential of a novel epididymal sperm protein SFP2 in a mouse model. American Journal of Reproductive Immunology 66 185-198. (doi:10.1111/j.1600-0897.2011.01030.x)

Khosrowbeygi A \& Zarghami N 2007 Fatty acid composition of human spermatozoa and seminal plasma levels of oxidative stress biomarkers in subfertile males. Prostaglandins, Leukotrienes, and Essential Fatty Acids 77 117-121. (doi:10.1016/j.plefa.2007.08.003)

Leeb T, Sieme H \& Topfer-Petersen E 2005 Genetic markers for stallion fertility - lessons from humans and mice. Animal Reproduction Science 89 21-29. (doi:10.1016/j.anireprosci.2005.06.021)

Loomis PR \& Graham JK 2008 Commercial semen freezing: Individual male variation in cryosurvival and the response of stallion sperm to customized freezing protocols. Animal Reproduction Science $\mathbf{1 0 5}$ 119-128. (doi:10.1016/j.anireprosci.2007.11.010)

Macias Garcia B, Gonzalez Fernandez L, Ortega Ferrusola C, Morillo Rodriguez A, Gallardo Bolanos JM, Rodriguez Martinez H, Tapia JA, Morcuende D \& Pena FJ 2011 Fatty acids and plasmalogens of the phospholipids of the sperm membranes and their relation with the postthaw quality of stallion spermatozoa. Theriogenology 75 811-818. (doi:10.1016/j.theriogenology.2010.10.021)

Mahdi BM, Salih WH, Caitano AE, Kadhum BM \& Ibrahim DS 2011 Frequency of antisperm antibodies in infertile women. Journal of Reproduction \& Infertility 12 261-265.

Manandhar G, Miranda-Vizuete A, Pedrajas JR, Krause WJ, Zimmerman S, Sutovsky M \& Sutovsky P 2009 Peroxiredoxin 2 and peroxidase enzymatic activity of mammalian spermatozoa. Biology of Reproduction 80 1168-1177. (doi:10.1095/biolreprod.108.071738)

Morris LHA 2005 Challenges facing sex preselection of stallion spermatozoa. Animal Reproduction Science 89 147-157. (doi:10.1016/j.anireprosci.2005.06.024)

Naz RK 2008 Immunocontraceptive effect of izumo and enhancement by combination vaccination. Molecular Reproduction and Development 75 336-344. (doi:10.1002/mrd.20783)

Novak S, Smith TA, Paradis F, Burwash L, Dyck MK, Foxcroft GR \& Dixon WT 2010 Biomarkers of in vivo fertility in sperm and seminal plasma of fertile stallions. Theriogenology 74 956-967. (doi:10.1016/ j.theriogenology.2010.04.025)

O'Flaherty C \& de Souza AR 2011 Hydrogen peroxide modifies human sperm peroxiredoxins in a dose-dependent manner. Biology of Reproduction 84 238-247. (doi:10.1095/biolreprod.110.085712)

Ollero M, Gil-Guzman E, Lopez MC, Sharma RK, Agarwal A, Larson K, Evenson D, Thomas AJ Jr \& Alvarez JG 2001 Characterization of subsets of human spermatozoa at different stages of maturation: implications in the diagnosis and treatment of male infertility. Human Reproduction $\mathbf{1 6}$ 1912-1921. (doi:10.1093/humrep/16.9.1912)

Paradisi R, Pession A, Bellavia E, Focacci M \& Flamigni C 1995 Characterization of human sperm antigens reacting with antisperm antibodies from autologous sera and seminal plasma in a fertile population. Journal of Reproductive Immunology 28 61-73. (doi:10. 1016/0165-0378(94)00911-P)

Shevchenko A, Wilm M, Vorm O \& Mann M 1996 Mass spectrometric sequencing of proteins silver-stained polyacrylamide gels. Analytical Chemistry 68 850-858. (doi:10.1021/ac950914h)

Smith TB, Baker MA, Connaughton HS, Habenicht U \& Aitken RJ 2013 Functional deletion of Txndc2 and Txndc3 increases the susceptibility of spermatozoa to age-related oxidative stress. Free Radical Biology \& Medicine 65 872-881. (doi:10.1016/j.freeradbiomed.2013.05.021)

Sun Z, Jin F, Li Y \& Zhang J 2010 Immunocontraceptive effect of DNA vaccine targeting fertilin $\beta$ in male mice. American Journal of Reproductive Immunology 63 282-290. (doi:10.1111/j.1600-0897. 2009.00785.x)

Tao Q, Fujimoto J, Men T, Ye X, Deng J, Lacroix L, Clifford JL, Mao L, Van Pelt CS, Lee JJ et al. 2007 Identification of the retinoic acid-inducible Gprc5a as a new lung tumor suppressor gene. Journal of the National Cancer Institute 99 1668-1682. (doi:10.1093/jnci/djm208) 


\section{A Swegen and others}

Varner DD 2008 Developments in stallion semen evaluation. Theriogenology 70 448-462. (doi:10.1016/j.theriogenology.2008.04.023)

Wakil SJ \& Abu-Elheiga LA 2009 Fatty acid metabolism: target for metabolic syndrome. Journal of Lipid Research 50 (Suppl) S138-S143. (doi:10.1194/jlr.R800079-JLR200)

Wang M, Lv Z, Shi J, Hu Y \& Xu C 2009 Immunocontraceptive potential of the Ig-like domain of Izumo. Molecular Reproduction and Development 76 794-801. (doi:10.1002/mrd.21027)

Whitten WK \& Biggers JD 1968 Complete development in vitro of the pre-implantation stages of the mouse in a simple chemically defined medium. Journal of Reproduction and Fertility 17 399-401. (doi:10. 1530/jrf.0.0170399)
Zhang CH, Li FQ, Yang AL, Sun W \& Miao JW 2007 Detection of anti-Sp17 antibodies in infertile patients' serum and its clinical significance. Zhonghua Nan Ke Xue 13 27-29.

Received 24 September 2014

First decision 29 September 2014

Revised manuscript received 28 November 2014

Accepted 11 December 2014 